\title{
Kentsel Planlamanın Yaban Hayatı ile İliş̧kilendirilmesi ve Değerlendirilmesi
}

\author{
İdris Oğurlu ${ }^{1}$, Leyla Suri ${ }^{2 *}$ \\ ${ }^{1}$ İstanbul Ticaret Üniversitesi, Mimarlık ve Tasarım Fakültesi Fakültesi, İç Mimarlık ve Çevre Tasarımı Bölümü, İstanbul, Türkiye, (ORCID: 0000-0002-2677-9513), \\ iogurlu@ticaret.edu.tr \\ 2* İstanbul Ticaret Üniversitesi, Mimarlık ve Tasarım Fakültesi Fakültesi, Mimarlık Bölümü, İstanbul, Türkiye (ORCID: 0000-0002-3225-1221), 1suri@ticaret.edu.tr
}

(İlk Geliş Tarihi 5 Kasım 2021 ve Kabul Tarihi 31 Aralık 2021)

(DOI: 10.31590/ejosat.1019722)

ATIF/REFERENCE: Oğurlu, İ., Suri, L. (2021) Kentsel Planlamanın Yaban Hayatı ile İlişkilendirilmesi ve Değerlendirilmesi, Avrupa Bilim ve Teknoloji Dergisi, (31), 906-915.

Öz

Bu makalenin amacı planlama sistemi içinde yaban hayatı işlev alanlarının yerini tespit etmek ve kentsel mekanda yaban hayatına yer vermenin yollarını araştırmaktır. Makalede; hayatına ve kentsel planlamaya ait temel kavramlar ve kentsel planlamanın temel kavramları ile planlama yaban hayatı ilişkileri ele alınmıştır. Kentsel mekanlarda yaban hayatına yer verebilmenin yolunun kentin yapılı çevresiyle birlikte doğal çevresini de şekillendiren Çevre Düzeni Planı ve bu plana göre detaylandırılan nazım imar planı ve imar uygulama planlarından geçtiği görülmektedir. Kentlerde yaban hayatına yönelik planlamaların öncelikle üst kademedeki planlarda ele alınması, yapılı ve doğal çevrenin, tüm plan kademelerinde bütüncül yaklaşımla planlanması gerektiği sonucuna ulaşılmaktadır.

Anahtar Kelimeler: Yaban Hayat, Planlama, İmar Uygulamaları, Kentsel Sistemler,

\section{Associating and Evaluating Urban Planning with Wildlife}

\begin{abstract}
The aim of this article is to determine the location of wildlife function areas in the planning system and to search for ways to include wildlife in urban space. In the article; The basic concepts of wildlife and the basic concepts of urban planning and the relationship between planning and wildlife are discussed. Wildlife in urban space is the subject of plans made together with the built environment. The mentioned plans are environmental plan, master plan and land use plans. It is concluded that the plans for wildlife in the cities should be handled primarily in the upper-level plans and the built and natural environment should be planned with a holistic approach at all plan levels.
\end{abstract}

Keywords: Wildlife, Planning, Zoning Applications, Urban Systems, 


\section{Giriş}

Kentlerin yol açtığı çevre problemleri sebebiyle, kentin çevresiyle uyum içerisinde olması gerektiği görülmüş ve kentlerin birer ekosistem olarak ele alınabileceği fikri kentsel ekoloji kavramını ortaya çıkarmıştır. Kent ekolojisi, kenti doğanın bir parçası olarak ve doğayı da kentin ayrılmaz bir parçası olarak değerlendirmektedir (Xiurui, 2005, Marzluff ve ark., 2008, Aydın, 2010). Bilindiği gibi, ekosistem canlı ve cansız unsurlardan meydana gelmekte olup şehirlerin yapılı çevresi ile bunun içinde yer aldığı toprak, iklim, topoğrafya, anakaya, yer altı-yer üstü su kaynakları gibi unsurlar sistemin cansız elemanlarını, şehir ortamında yer alan veya gelişen bitkiler ve hayvanlar ile, doğrudan ya da dolaylı etkisiyle insanlar ise sistemin canlı elemanlarını oluşturmaktadır. Bu çalışmada kent ortamının aynı zamanda yaban hayatına ait hayvan türlerine da yaşama mekanı oluşturabilmesin sağlamak için planlama bazında yapılması gerekenler irdelenmiştir.

Bilindiği üzere, sanayileşme ve kentleşme sebebiyle doğal alanların gitgide azalması sonucu şehir insanında ortaya çıkan doğa ile iç içe olma ihtiyacı günümüzde kent yeşil alanlarında giderilmeye çalışılmaktadır (Özgüner, 2003, Oğurlu, 2014)). Bu sebeple, gün geçtikçe insanların doğaya ve özellikle kentlerdeki doğal yeşil alanlara ve canlılara karşı ilgi ve duyarlılıkları artmaktadır.

Kentsel alanların yeşil örtüden ve çeşitli yaban hayvanlarından yoksun oluşu, kimliği hissedilmeyen bir şehirleşmeye yol açar. (Mol, 2006, Oğurlu, 2014). Oysa, planlanacak basit birtakım uygulamalarla bile şehir parklarını, okulların ve evlerin bahçelerini ve nihayet yeşil alanların tamamını çeşitli yaban hayatı türlerinin ziyaret edeceği veya barınabileceği ortamlar haline getirmek mümkündür. Bunun için yapılacak şey esasen; bu kısıtlı mekanlarda barınması istenen yaban hayvanları için su, barınak ve besin sağlayacak düzeni oluşturmak (Öymen, 2008), daha da önemlisi onlar için yaşama ortamı oluşturan bitki örtüsü ve benzeri yapıları korumak ve devamını sağlamaktır. Aslında çoğu şehirlerimizde kentin mezarlık, park, bahçe gibi yeşil alanlarında serçe, kumru, güvercin, nar bülbülü, iskete, saka vb yabani kuş türleri gözlenebilmektedir (Oğurlu ve ark. 2004). Bu türler için yeşil alan sathında yem değişimini sağlayan çitlembik, dut, yabani gül, asma, böğürtlen gibi ağaç ve çalıların bulundurulması kent hayatında yaban hayatına tanıklık edebilmek için yeterli olmaktadır (Mol, 2006). Ancak bu uygulamalardan önce temel bir mesele vardır ki o da bu konunun planlama sistemi içerisinde ele alınması ihtiyacıdır. Başka bir anlatımla; üst ölçek planlardan uygulama ölçeğindeki planlara kadar tüm tüm kademelerde; ölçekle uyumlu, kent yaban hayatını korumaya ve geliştirmeye yönelik hedeflerin belirlenmiş olması gerekmektedir.

Kentlerde yeşil alanların yanı sıra yaban hayatının da teşvik edilmesi gerektiği görüşü birçok modern peyzaj tasarımcısı ve planlayıcısı tarafından benimsenmiştir. Kentsel alanda yaşayan yaban hayvan türleri, gerek koruma gerekse peyzaj amaciyla yararlanma yönleri şehir plancısının, plan analiz aşamasında incelemesi gereken konular arasında olmalıdır. Kentlerde yaban hayatı için uygun yaşam ortamları oluşturma fikri günümüzde kent peyzaj tasarımının ayrılmaz bir parçası olarak kabul görmektedir. Yaban hayatını şehirlerde teşvik etme konusunda önemli ilerlemeler kaydedilmiş ve çeşitli rehber eserler (Flint 1985, Emery 1986, Özgüner, 2003 ) yayınlanmıştır.
Diğer yandan, kentsel alan çevresel alanlardan, yani kendisini çevreleyen tabiattan tamamen bağımsız olmayıp çevresindeki doğal varlıklardan, su kaynaklarından, bitki ve hayvan türlerinden etkilenir. $\mathrm{Bu}$ anlamda bir kentin fauna zenginliğini etkileyen üç temel faktörden bahsedilebilir: Bunlardan birincisi; kenti çevreleyen arazinin doğal zenginliğini oluşturan biyoçeşitlilik ve ekosistem çeşitliliğidir. Kenti kuşatan arazide yaşayan fauna türlerinin kentsel alanda da bulunma ve görülme şansı vardır.

İkinci faktör; kentin çevresindeki doğal alanlarla bağıbağlantısı-ilişkisidir. Mesela kent içindeki yeşil alanları kentin dışarısına bağlayan, bağlantı sağlayan yeşil koridorlar varsa kent içi yeşil alanlar bu koridorlar sayesinde tür ve popülasyon olarak doğadan beslenir. Örnek olarak İstanbul'un parklarını Kuzey Ormanları'na bağlayan yeşil koridorların planlaması verilebilir. Metropollerde bu anlamda kaçırılan ancak, gelişmekte olan iller için bugün de değerlendirilebilecek firsatlar vardır.

Üçüncüsü; kentin büyüklüğüdür. Kent büyüdükçe ve daha geniş bir sahaya yayıldıkça, merkezin (kentin merkezi kısımlarının) doğayla irtibatı azalır/zayıflar ve kentin - bitki ve hayvan türleri gibi- canlılar anlamında kendisini çevreleyen doğadan/kırsal alanlardan yararlanması güçleşir, yararlanma oranı düşer. Buna karşılık kırsal alanlara komşu kentsel alanlarda -yaşamaları için gerekli hayat şartlarını sağlayarak- bu komşu alandan bazı kuş ve memeli yaban hayvanlarının gelmesi beklenilebilir (Mol, 2006). Nihayet; kentsel mekanlarda yaban hayatına yer verebilmenin yolunun kentin yapılı çevresiyle birlikte doğal çevresini de şekillendiren Çevre Düzeni Planı ve bu plana göre yön verilen (detaylandırılan) nazım imar planı ve uygulama imar planlarından geçtiği gözden kaçırılmamalıdır. $\mathrm{Bu}$ bakımdan kentlerde yaban hayatına yönelik planlamaların öncelikle üst kademedeki planlarda ele alınması gerekmektedir.

\section{Gereç ve Yöntem}

Kentsel sistemlerde uygulamalar, mevzuat ve planlama kapsamında yapılmaktadır. Dolayısı ile planlama disiplini ve etki alanındaki mevzuat, çalışmanın en önemli materyalleridir. Aynı şekilde uygulama yetkisi bulunan kurumların görev ve yetki alanını belirleyen yasa ve yönetmelikler de çalışma kapsamını oluşturmaktadır. Bir tarafta yaban hayatının yaşam alanlarının içinde olduğu doğal ekosistem, diğer taraftan doğal sistemlere baskı oluşturan kentsel sistemler, kendi içinde analiz edilmiş ve sürdürülebilir gelişme doğrultusunda ortak paydaların araştırıldığı sentez yapılmıştır. Planlama hiyerarşisi bağlamında, bütünleşik yaklaşımla ele alınması gereken doğal ve yapay sistemler, hiyerarşi aşamalarına göre uygulanabilirlik hedeflenerek irdelenmiştir.

\subsection{Planlama Yaban Hayatı İlişkileri ve Kentsel Planlamanın Temel Kavramları}

Kentsel mekanda yaban hayatının yerini belirlemek için önce kentsel planlamanın planlama hiyerarşindeki yeri, yaban hayatıyla ilgili kentsel planların üst ölçekli planlarla ilişkisi bilinmelidir. Çünkü, kentlerdeki yaban hayatı unsurlarıyla ilgilenmek veya onlar için bir şeyler yapma ihtiyacı duymak aynı zamanda bu konuda bir planlama ihtiyacı duyulmasına da yol açacak ve sonuç itibariyle bir planlama aşamasına ulaşılacaktır. O aşamada ise yaban hayatı terminolojisiyle şehir planlamanın kavram ve terimleri birlikte telaffuz edileceğinden hem kentsel planlamada hem de yaban hayatında kullanılan temel kavram ve 
terimlerin bu konuyla ilgilenen yani şehir hayatında yaban hayatına yer vermeyi düşünen kimseler tarafından bilinmesi gerekmektedir.

Planlama sisteminde, kentsel ve kırsal alanları kapsayan planlar, hiyerarşik düzende ele alınmaktadır.

Planlama hiyerarşisi; ülkesel ölçekten yerel ölçeğe doğru geri besleme ile, kararların bütünlüğünü, devamlılığını ve tutarlılığını sağlamak üzere planlama sisteminin hiyerarşik bir düzen ve süreç içinde kurgulanmasıdır. Süreçte; ana hedef ve politikaların belirlenmesi, hedef için uygun seçeneklerin araştırılması, en uygun olanın seçilmesi, onaylanan plan kararlarının hayata geçirilmesi aşamaları mevcuttur ve bu aşamalar yasa ve yönetmeliklerle tanımlıdır.

İlgili yasalardaki yaklaşımlara göre planlama hiyerarşisi sosyo-ekonomik planlar ve fiziki planlar olmak üzere iki ana başlıkta incelenebilir (Tablo 1) (Suri, 2017).

\section{Tablo 1. Planlama hiyerarşisi}

\begin{tabular}{|c|c|}
\hline Sosyo Ekonomik Planlar & Fiziki Planlar \\
\hline $\begin{array}{ll}\text { - } & \text { Kalkınma Planı (Ülkesel) } \\
\text { - } & \text { Bölge Planı (Bölgesel) } \\
\text { - } \quad \begin{array}{l}\text { Mekansal Stratejik Plan } \\
\text { (Ülkesel, bölgesel...) }\end{array}\end{array}$ & $\begin{array}{ll}\text { - } & \text { Çevre Düzeni Planı } \\
& (1 / 50 \text { 000, 1/100 000) } \\
\text { - } & \text { Nazım İmar Planı } \\
& (1 / 5000,1 / 25000) \\
\text { - Uygulama İmar Planı } & \text { (1/1000) }\end{array}$ \\
\hline
\end{tabular}

Kentsel Peyzaj Planlarının; yasal plan hiyerarşisinde ayrıntılı olarak tanımlanmasa da, Almanya'daki yasal düzenlemede yer verildiği gibi (Güngöroğlu, 2008), fiziki planlar başlığı altında hazırlanarak kent planlarına adapte edilebilecek plan niteliğinde olması gerektiği söylenilebilir.

Ülkemiz yasal sisteminde, sosyo ekonomik planlar içinde bulunan "Kalkınma Planı", planlama hiyerarşisinin en üst kademesini oluşturur. 11. Kalkınma planında da belirtildiği gibi “.... doğal kaynakların kullanılmasında nesiller arası hakkaniyet ve sürdürülebilirliğin esas alınması" da hedefleri arasında yer alan çatı planı niteliğindedir. Beş yılda bir yapılması zorunlu planlardir.

Kalkınma planının aksine Bölge planları, hazırlanması zorunlu planlar arasında bulunmamaktadır. Doğal kaynaklar, yaban hayatı ve kentsel sistemler, birbiri ile sürekli iletişim kuran üst sistemin birer parçasıdırlar. Kentsel sistemlerdeki yaşam kalitesinin niteliği, yaşamsal kaynakların ve yaban hayatının sürdürülebilirliği ile doğrudan bağlantılıdır. Bu nedenle doğal sistem içinde, kaynakların niteliği, değeri (miktarı, kapladığ alan...) ve rejimi (sürdürülebilirliği) kısaca verimliliğinin, öncelikle üst kademe plan kararlarına bağlı olduğu açıktır. Kırsal ve kentsel birçok alanı; bölgesel ölçekte; kaynakların dengeli dağılımını sağlayan, koruyucu önlemleri sistem bütünlüğü içinde değerlendiren paylaşımcı, yaban hayatı için önemli olan yeşil sistemin devamlılığını da kapsayan ekolojik sürdürülebilir plan kararları, ancak üst kademe planlar kapsamında ele alınabilir. Toplumun sosyo ekonomik yapısı, gelişme eğilim ve talepleri ile doğal potansiyellerin, üst kademede ve tek potada değerlendirilebileceği bölge planları, yapılması, zorunlu planlar arasında değildir. Bölge planlarının yapılmaması yaban hayatı için önemli olan yeşil sistemlerin de; öncelikle delinme, devamında kopma ve azalma riskine maruz kalacağı anlamını taşımaktadır. Benzer şekilde; kent ortamındaki peyzaj strüktürünün bozulmasında çizgisel bariyer etkisi yapan yol ağlarının da (Forman, 1995, Deniz, 2006) bölgesel ölçekte ele alınması ve çözüm üretilebilmesi gerekmektedir. Bölgesel kademe kapsamındaki planlama sürecinde, mevcut türlerle birlikte bulunması gereken doğal sistemler, öncelikli olarak saptanmalıdır. Bölgedeki demografik yap1, sosyal, kültürel ve ekonomik faaliyetleri, beklentileri, eğilimleri ve yoğunlaşma alanları belirlenmelidir. Böylelikle bölgenin yapay ve doğal sistemi arasındaki ilişkinin yaratacağı etkiler, uygulama kademesine gelmeden detaylandırılabilecektir. Aynı zamanda; yoğun nüfus ve insan faaliyetinden kaynaklanabilecek antropojen etkiler görülmesi halinde sorun, farklı karakterde birçok yerleşmenin olduğu bölgesel kademede stratejik kararlarla çözülebilecektir.

Fiziki planların üst kademesinde çevre düzeni planları bulunmaktadır. Çevre düzeni planlarını nazım imar planı ve uygulama imar planı takip etmektedir. Sonraki bölümde ayrıntıları açıklanacak olan fiziki planlar da yasaların öngördüğü çerçevede hazırlanmaktadır. Parsel ölçeğindeki tüm uygulamalar, 1/1000 ölçekte hazırlanan "uygulama imar planı" doğrultusunda gerçekleşmektedir.

\subsection{Yaban Hayatına Ait Temel Kavramlar}

\subsubsection{Yaban Hayatı}

Ekolojik anlamda, yaban hayatı denince bir yerde insan müdahalesi olmaksızın yaşayan bitki ve hayvan topluluklarının meydana getirdiği hayat birliği anlaşılır. Bu birliğin unsurları, bitkiler ve mantarlar ile havyanlar aleminin böcek, sürüngen evcil olmayan- bütün kuş ve memeli türleridir.

\subsubsection{Yaban Hayvant}

Yaban hayatı evcil olmayan ve doğada serbest şekilde yaşayan bütün hayvan türlerini içine alır. Yaban hayvanları denilen bu türler, tabii yaşama ortamlarında genel itibariyle insan müdahalesi olmaksızın yaşarlar. Böyle olmakla beraber yaban hayvanları ve yaşadıkları ortamlar, yani habitatları insan etkisinden ve müdahalesinden muaf değildir. Mesela, insanların yaptığı tarım, hayvancılık, avcılık gibi faaliyetlerden yol, baraj vs inşaatlarından etkilenirler (Oğurlu, 2016). Yani, yaban hayvanları insanla temas ettikleri her yerde çeşitli tipte ve ölçüde etkilere maruz kalırlar. Yerleşim yerleri genişledikçe ve sıklaştıkça ve keza yerleşim alanlarına yaklaştıkça bu etkinin boyutu artar. Yerleşim yerine girildiğinde ise artık yabani hayvan için doğadakinden neredeyse tamamen farklı bir ortam söz konusudur. Çünkü orada hükmeden sadece doğa değildir, insan doğayı veya doğal şartları kendine göre değiştirmiştir. Bu şartlar altında yabani tür ya insanların yoğunlaştığı bu alana sözgelimi kente girmeyecek oradan uzak duracak ya da orada yaşamak zorunda kaldıysa o şartlara ayak uyduracaktır. İnsanın ona yardımcı olma niyeti ve gayreti varsa hayvanın da işi kolaylaşacak ve insanla birlikte kent sakinlerinden biri olmayı kabul edecektir.

Yaban hayatı denince, bugün, Dünyada ve ülkemizde, daha ziyade tabii yaşama ortamlarında yaşayan balık, sürüngen, kuş ve memeli hayvanlar anlaşılmaktadır. Ancak doğanın tamamen tahrip edilmediği ve doğal ortamların kaybolmadığı her yerleşim alanı ve bu arada kent ortamında yaşayabilen yabani hayvan türlerinin bulunmasından hareketle, doğal ve doğala yakın şartlara sahip ortamlar/alanları planlandığı takdirde kent hayatı ile yaban hayatının birbirine uzak kavramlar olmadıkları görülecektir. 
Özellikle çevresindeki bozkır, orman, göl, akarsu gibi doğal alanlarla irtibatı kopmamış kentlerin ve keza denizde kıyısı bulunan şehirlerin bu konuda daha şanslı oldukları ifade edilebilir.

\subsubsection{Tür Habitat ve Popülasyon Kavramlart}

Kentsel alanda yaşayan, yani kent ortamında barınan, beslenebilen türlerden bahsedildiğinde bunun üreyip yani neslini devam ettiren bir topluluk yani popülasyon oluşturduğu anlaşılmaktadır. Şu halde belli genişlikteki kentsel alanda üreme yoğunluğu denilen yoğunluğa sahip sayıda hayvan bireyinin bulunması gerekmekte ve yaban hayvanı popülasyonu bu yoğunluğun altına düşmedikçe ve yeterli besin ve barınak bulabildiği sürece varlığını devam ettirebilmektedir. Burada hayvanın beslenebileceği cinste ve miktarda besinin ve suyun ve yine arasında barınabileceği, yuvalanabileceği bir yapının bulunması gerektiğini de söylemek gerekmektedir. Bunlar yaban hayvanlarının temel ihtiyaçları olarak bilinir ve yaban hayatı literatüründe besin, örtü, su ve mekân adiyla 4 temel unsur olarak ifade edilir (Oğurlu, 2016).

\subsection{Yaban Hayvanlarının Temel İhtiyaçları ve Habitat}

Yaşama ortamı cansız ve canlı elemanlardan meydana gelir. Ortamın cansız elamanlardan iklim ve toprak faktörlerine bağlı olarak gelişen canlı elamanlar olan bitkiler ile toprak içinde yaşayan bakteriden böceğe kadar küçük organizmalar ve yine bitki örtüsü üzerinde veya arasında yaşayan her türden canlılar, yaban hayvanlarının besinini oluşturur. Böylece yaban hayvanlarının temel ihtiyaçlarının gözle görünen kısmını habitat unsurlarının /faktörlerinin oluşturduğunu söylemiş olmaktayız. Popülasyonun devamı için bir yerde besin, örtü ve suyun sadece mevcudiyeti değil dağılımı da belirleyicidir. Yani alan dâhilinde örtü, besin ve suyun bulunması yetmez; bunların aynı zamanda birbirine yeterli yakınlıkta ve hayvanın aynı gün içerisinde ulaşabileceği mesafe dâhilinde yer alması da gerekir (Oğurlu, 2016). Bu, kırsal alanda veya sözgelimi bir ormanlık alanda böyle olduğu gibi kentsel alanda da böyledir. Bu kapsamda kentsel alanda yaban hayatına yer verebilmek için habitat bileşenlerinin ve bu bileşenlerin ulaşılabilir/uygun mesafelerde bulunacak şekilde planlanması gerekmektedir.

İkinci bir husus olarak da kentsel alanda yaşayan ve yaşayabilecek yaban hayatı unsurlarının, yani hayvan türlerinin sayıl türlerden ibaret olduğunu-olabileceğini belirtmek gerekmektedir. Bu sayı en başta kentsel alanın kenti çevreleyen doğal alanlarla ne ölçüde bağlantılı olduğuna daha sonra da kentsel alanda yaban hayatı lehine yapilacak planlama kapsamındaki düzenlemelere bağlıdır. Bu düzenlemeler;

1. Yaban hayatı türlerine uygun mekanları korumak veya yeni mekanlar oluşturmak,

2. Yabani türleri barındıracak mekanlarda yeterli miktar ve dağıllımda örtü, besin ve su kaynağı bulundurmak ve bunların sürekliliğini sağlamak. (Mesela oluşturulacak bitki kombinasyonlarında yabani hayvanların yıl boyu besin ve barınak ihtiyaçlarını giderecek türlere yer verilmelidir (Öymen, 2008).

3. Yaban hayatı mekanlarını mümkünse birbiriyle bağlantılı bir ağ ve bir ekosistem şeklinde planlamaktır.

\subsubsection{Besin}

Besin, yaban hayatı habitatlarının en önemli unsuru olarak kabul edilir. Bir yerdeki besinin cinsi, miktarı, yıl içerisindeki değişimi, orada yaşayacak türlerin sayı ve miktarını belirler. Keza belirli bir türün bir habitatta barınabilmesi üzerinde en etkili ve çoğu zaman da belirleyici faktör, besin ve beslenme olmaktadır. Besin maddelerinin, topraktan başlayarak bitki ve hayvanlar mertebesine geçişi, ile bir "Besin zinciri” oluşur (Oğurlu, 2016). Buna göre kentsel alanın toprağı besinin ana kaynağıdır. Bu toprak üzerinde yetişen bitkiler ve bu bitkilerle beslenen hayvanlar kent içinde kente mahsus bir ekosistemin elemanları olurlar. Bu genişçe bir park veya yeşil alanda böyle olduğu gibi bir evin bahçesinde de böyledir. Mesela bir evin küçük de olsa bir bahçesi varsa bahçe toprağında barınan böcek ve solucanlar, bahçeye dikilmiş ağaç ve diğer bitkilerin tomurcuk, tohum ve meyveleri ve yine bu bitkilerin üzerinde yaşayan salyangozlar, tırtıl, sinek, arı ve kınkanatlı böcekler, kuşların besinini oluşturarak, o alanda çeşitli kuş türlerinin yaşayabilmesini sağlarlar.

\subsection{2. Örtï}

Örtü, yaban hayatını olumsuz hava şartlarından ve yırtıcılardan korurken, aynı zamanda yuvalanma, dinlenme ve beslenmelerini sağlar. Kentsel alanda kuru dallardan oluşturulan kümeler, birkaç kuru ağaç, taş ve küçük kaya kümeleri yabani hayvanlarının barınak örtüsü ihtiyacını karşılayacağı gibi bu ihtiyaç en önemlisi ağaç, çalı, otsu bitkilerden yeşil bir örtü oluşturularak sağlanır. Yeşil örtünün özellikle barınak sağlaması da yaban hayatı için büyük önem taşır (Öymen, 2008; Oğurlu ve ark. 2010.) Kızılgerdan ve sı ğırcık gibi açık alanları sevenler hariç bahçelerdeki pek çok kuş türü dinlenirken bir ağacın veya çalının korumasını tercih eder. Daimi yeşil gelişmiş bir ağaç, kuşların gecelemesi için mükemmel bir yer oluşturur. Özellikle böyle ağaçların yapraklı dalları kış mevsiminde buralarda konaklayan kuşları ıslanmaktan ve üşümekten korur. İğne yapraklı ağaçların dalları yağmur ve karın ağacın iç kısımlarına ulaşmasını engellerken dondurucu soğukların etkisini de azaltır. Çit bitkileri ve çalılar da bazı kuş türleri için uygun konaklama yerleridir. Bahçelerde kuşların yuva yapacağı yerlerin yetersiz olması halinde çeşitli tipte yapay yuvalardan yararlanılabilir (Öymen, 2008).

\subsection{3. $\mathrm{Su}$}

Yaban hayvanlarının mutlak fizyolojik ihtiyaçlarından biridir. İçme suyu ihtiyaçları bakımından, türler büyük ölçüde değişiklik gösteriyor olsa da hayvanın yaşadığı çevrede ulaşabileceği mesafede su bulunmalıdır. İçme suyuna bağımlı türlerde, bir populasyonun sahadaki yoğunluğu, su kaynaklarının dağılımıyla sınırlanır. Suyun bulunduğu noktalarda miktarı ne olursa olsun (su, ne kadar bol da olsa) ancak sinirlı sayıda hayvanın bu alanda barınmasına hizmet edebilir. Aktüel sınırlamayı ise genellikle su kaynağı civarındaki besin miktarı yapar. Bu bakımdan populasyonun yoğunluğunu arttırmak için su kaynakları ile birlikte besin kaynaklarını da geliştirmek gerekir Çünkü yaban hayvanları su bulamadıkları yerde besine de pek iltifat etmezler. Suyun yetersiz olduğu bir ortama giren az miktardaki suyla birlikte, daha önce kullanılamayan birçok besin maddesi de kullanılır hale geleceğinden, az miktardaki su bile ortamda olumlu yönde büyük bir değişikliğe yol açabilir (Oğurlu, 2016).

\subsubsection{Mekan (Yer)}

Habitat bileşenleri olan örtü, besin ve su kaynakları ancak belirli genişlikteki bir alan üzerine yerleşebileceklerinden habitatın diğer bir bileşeninin de yaşama alanına tekabül eden ve farklı türler için değişen genişlikte mekanlar olduğunu 
söyleyebiliriz. Her türün ihtiyaç duyduğu mekan genişliği farklıdır. Kent faunasından olan salyangoz, fare gibi türlerin daha kısa mesafeler dahilinde hareket ettiğini, kumrunun onlardan daha geniş bir dairede uçup konduğunu, martının ise çok daha geniş bir daire çizdiğini günlük hayatta gözlenmektedr.

\subsection{Habitat Unsurlarının Dağılımı}

Habitatı vücuda getiren ve habitat unsurları da denilen besin, örtü, suyun sadece varlığı ve miktarları değil habitat içerisindeki dağılımları da habitatın kalitesi ve kullanımı açısından önemli rol oynar. Çünkü hayvan yaşadığı mekânda habitat ihtiyaçlarından her birini, yani besini, örtüyü ve suyu günlük aktivitesi sırasında birbirine yakın mesafelerde bulabilmelidir. Bu bakımdan, habitat unsurlarının alandaki dağılım ve mesafeleri, habitatın yeterliliğini ve kalitesini belirleyen en önemli parametrelerden biri olmaktadır.

\subsection{Kent Hayatında Yaban Hayatına Hayvanlarına Yer Vermeyi Gerektiren Sebepler}

Şehir planlamada yaban hayvanlarına yer vermeyi gerektiren başlica sebepler şunlardır:

- Yaşamsal kaynakların sürdürülebilirliği, flora ve faunayı birlikte ele almayı gerektirir.

- Yaban hayatını oluşturan unsurlar kent sakinlerinin kendilerini doğada hissetmelerini sağlar.

- Yaban hayatı unsurları kentte yaşayan doğa severlere yaşama sevinci verir.

- Yaban hayvanları, şehirde yaşayan çocuk ve gençlerin doğa ve doğal varlıkları tanıyıp severek gelişmelerini sağlar.

- Yaban hayatı unsurları; kuşlardan balıklara kadar çevre sağlığının mükemmel göstergeleridir.

- Yaban hayatı unsurları aynı zamanda peyzaj düzenlemede kullanılan peyzaj elemanlarıdırlar.

- Yaban hayatı unsurları aynı zamanda ülkemizi biyolojik zenginliğinin bir parçasını oluşturmaktadır.

\section{Araştırma Sonuçları ve Tartışma}

Kent hayatında yaban hayatına yer vermenin yol ve yöntemleri sadedinde sözlenecek ilk söz tabiidir ki yaban hayatının planlama hiyerarşisindeki yerini alması gerektiğidir. Dah üst ölçekli plandan aşağı inildikçe uygulama detayı artacak ve nihayet kent içinde yabani unsurlara hitap edecek mekanların planlanması ve tasarlanmasina gelinecektir. Elbette bu arada uygulamaya yön veren birtakım prensipler de bulunmaktadır. Mesela, tasarlanacak-düzenlenecek mekânda suni unsurların çoğalması ve doğallıktan uzaklaşma yaban hayatını olumsuz etkiler. Bu sebeple tasarım ve uygulamada doğallık esastır. Özel bakım gerektiren ekzotik bitki türlerini mümkün olduğunca az kullanıp, onun yerine yerli türler tercih edilmelidir. Pestisitlerin kullanımını minimuma indirmek ve biyolojik mücadeleyi ön plana çıkarmak gerekir (Öymen, 2008).

\subsection{Planlama Kademelerinde Yaban Hayatının Rolü, Envanteri, Analizi ve Değerlendirilmesi}

\subsection{1. Çevre Düzeni Planında Yaban Hayatının Değerlendirilmesi}

Kentsel yerleşime / iskâna yeni açılacak alanlarda yaban hayatının planlanması, yeni kentsel alanlara yönelik yerleşim planları için benimsenen yaklaşım ve imara açılacak alanlarda yaban hayatına yönelik planlamanın karakteri, alan iskan edildikten sonra kentin yaban hayatı üzerinde en belirleyici faktör olacaktır. İskâna açılan bir arazide mevcut bitki örtüsü ve su kaynaklarından, hedeflenen yaban hayatı unsurları için; kent ortamındaki yeşil sistemin bütünlüğünü sağlayacak ve sistem bileşenleriyle bağlantı kurabilecek nitelikteki kısmının, doğal alan olarak bırakılmasını sağlayacak bir plan yaklaşımı gereklidir. Böylece hem kentin yeşil alan ihtiyacını karşılama hem de yaban hayatına yer ayırma amaçlarına hizmet edilmiş olur. Farklı bir anlatımla; imara açılacak alanların yapı ve nüfus yoğunluğunun niceliği ve işlev alanlarının niteliği, sürdürülmesi hedeflenen yaban hayatının taşıma kapasitesine göre belirlenecektir.

Bir alanın tasarımında genellikle o alanda halihazırda bulunan doğal bitki türlerinin kullanılması estetik ve sürdürülebilirlik açısından daha uygun görülmektedir. Zira, doğal türlerin genellikle bölgenin tabiat şartlarına adapte oldukları ve bir çok hayvan türünü üzerinde barındırdığı ve dolayısıyla sürdürülebilir peyzaj açısından daha uygun olduğu düşünülmektedir (Kennedy and Southwood 1994; Özgüner 2003). Bu durum aynı zamanda bakım onarım maliyeti açısından da ilgili idareye ekonomik katkı sağlayacaktır.

Bilindiği gibi, yerleşme alanları, doğal alanlara doğru farklı şekillerde; merkez etrafında yağ lekesi gibi, doğal ya da yapay akslar boyunca lineer, topografyanın elverdiği ölçüde ya da merkezden koparak atlama yapan ufak nüveler oluşturup saçaklanarak genişlemektedir. Yaban hayatının; yerleşme çeperlerindeki doğal çevreden, merkeze kadar devamlılığının sağlanması, öncelikle; kırsal ve kentsel alanın bir arada değerlendirildiği çevre düzeni planı kararları ile güvenceye alınmalıdır. Birden fazla kırsal ve kentsel yerleşme deseninin birlikte değerlendirilmesi; yaban hayatının, birbirini tamamlayan tür çeşitliliğinin sağlanabilmesi için de zorunlu görünmektedir. $\mathrm{Bu}$ nedenle; yaban hayatının detaylarıyla, kapsamında olduğu peyzaj planlama hiyerarşik planlama sistemi paralelinde; öncelikle kent kademesinin üzerindeki kapsamda ele alınarak çevre düzeni planına adapte edilecektir ki belirtilen kademede ölçekler, 1/50000-1/100000 aralığında bulunmaktadır. ÇDP plan paftalarında; yaban hayatı yaşam alanlarının, genel sınırlarına ilişkin stratejik kararlar, kent kır arasındaki sürekliliği, alt kademelere veri sağlayacak türlerin genel açıklamaları, yerleşmeler bütününde fiziksel peyzaj strüktürü, plan raporunda ilkesel peyzaj kararları yer almaktadır. ÇDP; alt kademesinde bulunan nazım imar planlarına; plan paftası, lejantı, plan notları ve plan raporunda, habitat düzeyindeki genel kararlara ilişkin yönlendirme yapabilecek, net, anlaşılır veri sunabilmelidir. Nazım planlarda; ÇDP'nın genel ve ilkesel kararları, imar adası detayına girmeden yer almaktadır. Alt bölgeler çerçevesinde, flora ve faunaya ilişkin açıklamalar, popülasyon yoğunluğu vb. detaylar plan paftası-plan notları ve plan raporunda bulunabilir. Yaban hayatının sürdürülmesinde de önemli bir kademe olan ÇDP'nın, güncel mevzuatta yapılması zorunlu planlar kapsamında olması gerekmektedir. Nazım imar planında, yaban hayatına olanak sağlayan yaşama alanlarının sürekliliği, kentsel ölçekte izlenebilir., Bu aşamada kentsel peyzaj planı, hiyerarşik sistem paralelinde, 1/25000 ya da 1/5000 nazım plan ölçekleri ile detaylandırılarak nazım plan bütünlüğü içinde plana dahil olacak ve gene aynı şekilde alt kademe planları yönlendirecektir. Yukarıda da belirtildiği gibi, nazım planlarda imar adası ve küçük komşuluk grupları görünmemektedir. Ad1 geçen birimler, uygulamaya da esas olan uygulama imar planlarında yer almaktadır. Uygulama İmar Planlarında, tüm imar istikametleri, 
nihai konumu ile görünür. Belirtilen bu istikametler, uygulamada alana aplikasyonu yapılacak kesin sınırlardır. Aynı zamanda, istikametler arasında kalan alanların işlevi de üst kademe plan kararı doğrultusunda detaylandırılır. Yaban hayatının sürekliliğine olanak sağlayan işlev alanlarının son halkası; küçük komşuluk, grupları arasındaki konumu ile yapay çevrenin en alt kademesine kadar devam eder. Küçük komşuluk grupları arasından da kılcal bağlantılarla, sirkülasyonunu devam ettirir. Uygulama imar planı; işlev alanlarının kesin sınırı, kullanım yoğunluğu, tür çeşitleri, bakım ve onarımından sorumlu kurumlar vb. tüm ayrıntıların görülebileceği detayları içermektedir. Plan kararları; plan paftasında çizimle, lejantta çizgi ve sembollerin açıklaması ile, plan notlarında paftada açıklanamayan uygulamaya ilişkin özet anlatımla ve raporda tüm plan kararlarının ölçek doğrultusunda geliştirilen kararları ile ifadelendirilebilir. Buraya kadar anlatılan, yeni yerleşime açılacak yerlerdeki yaban hayatının planlaması aşağıdaki gibi özetlenebilir; Her kademedeki plan; hazırlık aşamasında yapılan geniş kapsamlı analizlere göre ilerlemektedir. Doğal yapı özellikleri, hem bölgenin doğal potansiyelinin korunarak geliştirilmesi hem de insan sağlı̆̆ açısından, son derece önemlidir ve bu amaçla; analizlerde detaylı envanter çalışması yapılır. Dolayısı ile bölgesel ölçekte bölge planı ve ÇDP ölçeğinde; bölgedeki mevcut flora ve fauna, nitelik ve niceliği ile birlikte, biyotop haritaları yapılarak analiz edilir. Mevcut ve önerilen yaban hayatının sürdürülebilirliğini sağlayacak flora; alan büyüklüğü, yer seçimi ve niteliği, bu kademede belirlenir. ÇDP kademesinde; yaban hayatının sürdürülebilirliğini sağlayan işlev alanları, ilkesel kararlarla ifade edilebilir. ÇDP fiziki planlardaki işlev alanları sınırları, alt kademe planlara ilkesel kararlar ile birlikte yol gösterir. Bölgesel ya da birkaç ili, kırsal ve kentsel yerleşmeyi kapsayabilecek ölçekteki ÇDP, kent ile kırsal alan ilişkisini kuran, başka bir ifadeyle yeşil sistemin devamlılığını sağlayan, genel ilkelere göre nicelik ve niteliğini belirleyen bütüncül plan yaklaşımı ile alt kademeye veri sağlayan plan niteliğindedir.

Mevcut kaynakların bölgeye sağlayacağı yarar ve yapay çevrenin kaynaklar üzerindeki baskısı, hinterlant ilişkileri ile üst ölçekte ele alınır, yerleşmelere atanacak yeni yoğunluk ve kimlik değerlerine göre ÇDP hazırlanır. Genel ilkeler ve kullanımlar ÇDP'nda belirlenerek alt kademe planlarına kaynak oluşturur. ÇDP, kırsal-kentsel birçok yerleşme arasındaki bağlantıların izlenebileceği bir kademededir. Nazım plan kapsamı ise kent bütünü ya da kentin herhangi bir alt bölgesidir. Başka bir anlatım ile verilerin, üst kademe ÇDP'dan alınarak detaylandırıldığı kademededir. Bölge planları ve ÇDP, birden fazla idari birimin bulunduğu kırsal ve kentsel alanı kapsayabilir. Ancak nazım plan, genellikle tek bir idari sınır kapsamında yapılmaktadır. Dolayısı ile ÇDP'da devamlılık arzeden yeşil işlev alanları, nazım planda sadece ilgili idari sınır (ilçe, alt bölge..) kapsamında uygulama görebilir. Bu nedenle, yaban hayatı yaşam alanlarını oluşturan yeşil sistemin, kent bütünü ve kırsal alanla bağlantısını sağlayan kademenin, çevre düzeni planı olduğu ifade edilebilir. Genel yaşam alanları ve sistemin sürekliliğinin tasarım kararlarını içeren ÇDP'nın, alt kademelerinde, flora ve faunanın uygulama kademesindeki detaylandırmalar yer alacaktır.

En alt basamaktaki uygulama planı, işlev alanlarının dolayısıyle yaban hayatı alanlarının fiziksel anlamda araziye aplikasyonuna esas oluşturan istikametleri kapsamaktadır, 1/1000 ölçekte, kentsel tasarıma-peyzaj uygulama projesine 1 ş1k tutacak ayrıntıları da içermektedir.

\subsubsection{Nazım Imar Planlarında Yaban Hayatının Değerlendirilmesi}

Önceden iskan edilmiş kentsel alanlarda yaban hayatının planlanması aşamasında kentsel alanda mevcut ve potansiyel yaban hayatı unsurlarının ve ihtiyaçlarının belirlenmesi ve kentte mevcut yaban hayvanlarının ve durumlarının tespiti çalışmaları yer alacaktır.

Şehirde ve kentsel alanlarda yaşamakta olan türlerin tespiti yapılacak ilk iştir. Bu çerçevede yapılacak işlerin başında; mevcut türlerin kent içindeki yerleri, yani bunların görüldüğü, barındığı, ürediği yerlerin ve bunların kent alanındaki dağılımlarının belirlenmesi gelir (Oğurlu, 2003). Bu arada, mevcut türlerin güncel ve potansiyel ihtiyaçlarının ve varsa yaşadıkları problemlerin de tespiti gerekir ki belirtilen tesbitler başta çevre düzeni planı olmak üzere, nazım imar planı ve uygulama imar planı ön hazırlığında ve revizyonunda, doğal yapı başlığında yer alması gereken önemli analizler arasındadır. Yerleşik alanlarda kentsel peyzaj planlamaya ilşkin revizyon ve rehabilitasyon; öncelikle, bir taraftan üst ölçek ÇDP'nın alt ölçek nazım plana aktaracağ 1 verilerin incelenmesini, diğer taraftan nazım plan ölçeğinde, yaban hayatı yaşam alanlarının, plana aykırı gelişmiş kısımlarının tesbitini gerektirmektedir. İlgili uzmanlık alanları ile planlamaya multidisipliner yaklaşım, plan uygulamalarındaki verimliliği de artıracaktır. İskan edilmiş alanlarda, "mevcut ve potansiyel yaban hayatı unsurlarının ve ihtiyaçlarının belirlenmesi", nazım plan kademesinde ele alınacaktır. Mevcut ve potansiyel yaban hayatı yaşam alanlarının meri nazım planda ve uygulama imar planında bulunmaması halinde; kaynak alanları plan kararları olarak, nazım ve uygulama imar planlarına eklenebilmelidir. Belirtilen plan kararları; yerleşme alanı ya da mahalle alt bölgesinin tamamına hitap eden kullanım alanı ise nazım imar planına, komşuluk grupları detayında ise imar uygulama planlarına işlenecektir.

\subsubsection{Uygulama Imar Planlarında Yaban Hayatınin Değerlendirilmesi}

Yeni getirilebilecek türlerin tespiti aşamasında, şehirde mevcut olmayan, fakat şehirde yaşamalarına uygun yerler bulunan veya kendileri için uygun şartlar/ortamlar oluşturulabilecek türlerin bulunup bulunmadığı tespit edilir. Potansiyel bu türlerin biyolojileri ve ekolojik istekleri bakımından iyi etüt edilmesi gerekmektedir.

\subsubsection{Kentsel Tasarım Sürecinde Yaban Hayatının Değerlendirilmesi}

Mevcut ve potansiyel türlerin biyolojileri ve ekolojik isteklerinin belirlenmesi sürecinde, kent ortamında görmek istediğimiz türlerin varlığı her şeyden önce onların biyolojileri ve ekolojik ihtiyaçlarının bilinmesi gerekir. Bunların yaşamayı sürdürmesi de bu ihtiyaçların plan süresi boyunca gözetilmesi, plan uygulamalarında buna uygun hareket edilmesi ve planlanan çalışmaların hayata geçirilmesiyle sağlanır.

\subsection{Kent Hayatında Yaban Hayatına Yönelik Farkındalık Aktiviteleri}

Büyük şehirlerdeki dönüşüm; toprak yüzeyinin ve yeşil kitlenin azalması yönünde cereyan etmektedir. İlk yapılacak iş bu gidişin durdurulması, yeşil kitleyi oluşturan ağaç-çalı ve her türlü bitkiyle oluşan bitki örtüsünün ve bunun besleyen toprak zeminin korunmasıdır. Yaban hayatına da ortam oluşturan yeşil dokunun sürdürülebilirliği, kentsel ve kırsal alana bütüncül yaklaşım 
getiren uluslararası çalışmalarda da ifade edilmektedir (Tuna. 2021). Bu hedefe yönelik olarak fiziki planlarda planlama hiyerarşisi içerisinde Çevre Düzeni planından, kentsel peyzaj planlarına kadar alt/ara hedefler sözkonusu olup bu hedefler istikametinde yapılması gereken çalışmalar bulunmaktadır. Aşağıda sırayla bu çalışmalar anlatılmaktadır: Planlamanın tüm kademeleri, ekolojik temele dayandırılmalıdır. Bununla birlikte, peyzaj planlamanın öncellikle; "environmental planning" kavramı ile denk düşen ve aynı zamanda, fiziki planlama hiyerarşisinin üst kademesinde bulunan ÇDP ile paralel ele alınması gereken niteliğe de sahip olduğu söylenilebilir. $\mathrm{Bu}$ aşamada detaylı doğal yapı analizleri; mevcut ve geliştirilebilir flora/faunanın sürdürülebilirliğini sağlayan ölçütler hakkında sentez yapılabilecek veri tabanını oluşturacaktır. Diğer bir ifadeyle burada peyzaj planlama fiziki sınıflama kademesinde "çevre düzeni planı” ölçeği kapsamında da yer almaktadır. Daha ayrıntılı açıklamak gerekirse; yasal sistemdeki fiziki plan hiyerarşisinde; ÇDP, Nazım İmar Planı, Uygulama İmar Planı şeklinde yer alan planlar,; ulaşım, peyzaj altyapı, vb. başlıklarında yapılan tüm planların bir araya getirildiği yasal dokümanlardır. Bu nedenle, her kademe fiziki plan; yukarıda alt başlıklarda ifade edilen planların da kademesine işaret etmektedir. Dolayısı ile; yaban hayatı alanları; kentsel ve kırsal birkaç yerleşmeyi kapsayan üst kademede ÇDP, yerleşme tamamını kapsayan (genellikle ilçe idari sınır) kademede nazım imar planları, imar adası detaylarının görüldüğü kademede, uygulama imar planı kapsamında ele alınacaktır. Ayrıca, plan onamasını takip eden süreçte hazırlanacak kentsel tasarım projelerinde; en alt kademede detaylandırılan peyzaj planları verilerini kapsayacak şekilde, flora fauna mikro ölçekteki yaşam alanları, büyüklükleri konusunda, plan ölçeğinden daha ayrıntılı detaylar görülebilecektir. Planlama hiyerarşisi içerisinde tüm kademelerin, peyzaj ekolojisini referans aldığı bir yapı halinde olması gerekir. Gerekli biyotop, peyzaj onarımı ve koruma kararlarını barındıracak nitelikte olmalı. Bu kararlar da sadece yeşil alanlara yönelik değil, yapılı çevre ile de birlikte düşünülmelir (peyzaj fonksiyonu: su yönetimi, iklim düzenleme vb.). Ülkemizdeki planlama çalışmalarında, ekolojik temelin esas alınması gerektiği burada bir kez daha vurgulanmalidir.

\subsection{1. Çevre Düzeni Planı ile Bağlantılı Çalışmalar}

Çevre düzeni planı (Ç.D.P.) kırsal-kentsel alanlarda, birden fazla yerleşmeyi kapsayacak ölçeklerde hazırlanmakta, sosyo ekonomik planlardan fiziki planlara geçiş aşamasında, stratejik planlardan veri almaktadır. "Orman, akarsu, göl ve tarım arazileri gibi temel coğrafi verilerin gösterildiği, kentsel ve kırsal yerleşim, gelişme alanları, sanayi, tarım, turizm, ulaşım, enerji gibi sektörlere ilişkin genel arazi kullanım kararlarını belirleyen, yerleşme ve sektörler arasında ilişkiler ile koruma-kullanma dengesini sağlayan $1 / 50.000$ veya $1 / 100.000$ ölçekteki haritalar üzerinde ölçeğine uygun gösterim kullanarak bölge, havza veya il düzeyinde hazırlanabilen, plan notları ve raporuyla bir bütün olarak yapılan planlardır” (R. G. 2014) Çevre düzeni planı kapsamındaki yerleşmelerin doğal yapı analizleri, bu aşamada son derece önem arzetmektedir. Şöyle ki;

- Kentsel-kırsal nüfus büyüklüğü ve nüfus yoğunluğu, plandaki fonksiyon alanlarının büyüklüğü ve yer seçiminde en önemli unsurdur.

- Nüfus büyüklüğü ve yoğunluğunun belirlenmesinde; bölgedeki gelişmeler ve eğilimler etkin rol oynamaktadır. Çevre düzeni kademesindeki analizlerin, nüfus yoğunluğunun belirlenmesindeki en önemli etkisi; plan alanının doğal varlıklarının sürdürülebilirliğini sağlayan doğal ve kültürel eşik değerleri olmalıdır.

- Farklı bir anlatımla; doğal eşiklere ilişkin ölçütler, bölgeye gelecek nüfus ve fonksiyon alanlarının, niceliği ve niteliğini belirleyen kırmızı çizgileri oluşturmalıdır.

- Sözü edilen ölçütler doğrultusunda; çalışmanın başlığını oluşturan "Kent Hayatında Yaban Hayatına Yer Vermek" konusuna, "yaban hayatının sürdürülebilirliği (ya da kentin taşıma kapasitesi) bağlamında yerleşme makroformu ve nüfusunu belirlemek" yaklaşımı ile bakmak, çalışma amacının daha iyi anlaşılmasını sağlayacaktır.

Özetle belirtmek gerekirse; mevcut ve öneri yaban hayatının korunmasında ve sürdürülmesinde çevre düzeni planının en önemli rolünün; taşıma kapasitesi ya da eşik değerlerin tesbiti ile, yerleşme alanlarının makroformunu, nüfus büyüklüğünü, başlıca işlevleri, nüfus ve işlev alanları yoğunluk ve yer seçimini belirlemesi olduğu söylenilebilir. Bu yapıldığı takdirde bütüncül bakış yaklaşımı ile; doğal ve yeşil alanların kentten kırsal alanlara doğru devamlılı̆̆ sağlanmış ve alan kaybı önlenmiş olacak, böylece yaban hayatı da dahil olmak üzere doğal varlıklara ve canlı türlerine yaşama mekanları bırakılmış olacaktır.

\subsubsection{Nazım İmar Planı ile Bağlantılı Çalışmalar}

Yerleşmenin idari sınır kapsamında işlev alanlarının devamlılığı, kademesi nazım imar planlarında görülebilmektedir. Dolayısı ile ÇDP'dan gelen yönlendirme ile yaban hayatının idari sınır (genellikle ilçe kademesinde) bütününde yaşayacağ bölgeler, koridorlar, atlama mekanları, bu kademede topluca görünmektedir. Nazım imar planı ilgili yönetmelikte "Mevcut ise çevre düzeni planının genel ilke, hedef ve kararlarına uygun olarak, arazi parçalarının genel kullanış biçimlerini , başlıca bölge tiplerini, bölgelerin gelecekteki nüfus yoğunluklarını, çeşitlik kentsel ve kırsal yerleşme alanlarının gelişme yön ve büyüklükleri ile ilkelerini, ve uygulama imar planlarının hazırlanmasına esas olmak üzere, arsa kadastral durumu işlenmiş olarak 1/5.000 ile $1 / 25.000$ arasındaki her ölçekte, plan notları ve ayrıntılı raporuyla bir bütün olarak hazırlanan plandır" şeklinde tanımlanmaktadır (R. G. 2014).

Nazım imar planlarının, yapılması zorunludur ancak tanımdan anlaşılabileceği gibi; çevre düzeni planlarının yapılması zorunlu görülmemektedir. Nazım imar planlarının, hazırlamaonaylama-uygulama yetkisi, sadece kendi idari sınırları içinde sorumluluğu olan yerel yönetime (belediye) verilmiştir. $\mathrm{Bu}$ nedenle ilgili yerel idarelerin, üst ölçekli plan olmaksızın sadece yetki sınırları dahilinde yapılan nazım imar planlarının, yaban hayatı açısından, parçacıl nitelik taşıdığı söylenilebilir. Belirtilen durum, bütüncül yaklaşımdan uzaktır ve yaban hayatının sürdürülebilirliği açısından risk taşıyan uygulamaların önemli sebepleri arasındadır.

Daha önce de değinildiği gibi, çevre düzeni planı birden fazla yerleşmeyi içine alan, doğal ve kültürel varlıkların yapay çevre ile etkileşimini tek potada değerlendiren, taşıma kapasitesine göre yerleşmelerin yön ve büyüklüğünü, makroformunu, işlevini, yoğunluğunu, vizyon ve misyonunu belirleyici rolü olan, alt ölçek planlara bu yönde veri sağlayan, üst yönetimin kontrolünde olması gereken bir kademedir (Suri 2020).

Çevre düzeni planı bulunan alanlarda yapılan nazım imar planları ile; çevre düzeni planında genel işlev ve sınırları belirli alanlar, yukarıda belirtilen ölçek aralıklarında detaylandırılmaktadır. Nazım imar planlarında, mahalle alt 
bölgesinin tamamına hizmet veren; yeşil alanlar, birinci ve ikinci kademe ulaşım arterleri, adalar (ada ayrıntıları 1/1000 ölçekli imar uygulama planında görünür) topluluğu, nüfus yoğunluğu ve başlıca işlevler görünmektedir. Bu plan hazırlanırken yaban hayvanlarının habitat haritaları ve baskı unsurlarının dağılım haritası dikkate alınmalıdır.Nazım plan, yaban hayatına yaşam alanı sunan yeşil devamlılığını 1/1000 ölçekli planlara veri sağlayacak şekilde genel hatları ile ele almalıdır.

\subsubsection{Imar Uygulama Planı ile Bağlantılı Çalışmalar}

Uygulama imar planları, planlama kademesinde yapılması zorunlu planlar arasındadır. "Nazım imar planı ilke ve esaslarına uygun olarak yörenin koşulları ve planlama alanının genel özellikleri, çevreye etkisi dikkate alınarak; yapılaşmaya ilişkin yapı adaları, kullanımları, parkları, meydanları, gibi yapılaşma ve uygulamaya ilişkin kararları, gösteren 1/1.000 ölçekte plandır (R. G. 2014) Uygulama imar planları, plan kararlarının mekânsal boyutu ile araziye aplike edildiği kademededir. Nazım imar planında genel sınırları belirli yaban hayatı yaşam alanlarının uygulama ölçeğinde detaylandırılarak gösterildiği planlardır.

Ada bazında, nazım imar planında ölçeği gereği gösterilemeyen ayrıntılar da uygulama imar planında gösterilebilir ancak, yaban hayatı için süreklilik arzetmesi gereken fonksiyon alanlarının öncelikle nazım imar planı ve çevre düzeni planları kapsamında ele alınması gerekliliği bulunmaktadir.

Üst ölçekli planlarda bulunmayan ve sürekliliğinin sağlanması yaban hayatı için önemli olan yaşam alanlarının, kamuya ait mülkiyetin yetersiz olduğu uygulama imar planı kapsamında yer alması ve uygulanabilmesinde mülkiyet hakları nedeni ile güçlükler yaşanması olasılığı yüksektir. Uygulama imar planında yaban hayatına yönelik ana hedef esasen; mevcut su kaynakları ve keza doğal bitki örtüsünün mevcut bulunduğu yerlerden belirli bir kısmı yapılaşma dışında tutmak veya tamamen yaban hayatını koruma odaklı planlamaktır. Keza, şehrin yeşil alan miktarını mümkün olduğunca yüksek tutmak da bu aşamadaki temel hedeflerden biridir. Belirtilen durum, uygulama imar planında ada bazında yapılaşma sınırlarının kısmen ya da tamamen tanımlanması, plan notları ile de detaylı ifadelendirilmesi ile mümkün olabilir. Özellikle yerleşik alanlarda yaban hayatı yaşam alanlarının günden güne azalması nedeniyle, sürekliliği, yatayda ve düşeyde sağlayabilecek; yumuşak zemin, bina çekme mesafeleri, bina-yol, bina-bina ilişkisi, cephe ve çatıda yaban hayatının süreklilkiğini sağlayabilecek uygulamaların açıklamaları, plan notlarında bulunmalıdır.

\subsubsection{Kentsel Peyzaj Planlama ile Bağlantılı Çalışmalar}

Şehrin peyzaj planında konumuzla ilgili temel hedef her türlü peyzaj uygulamasında peyzaj amaçları yaban hayatı ve doğal alanların birlikte ele alınması olmalıdır.

Yaban hayatının korunması en başta, doğrudan doğal alanların korunmasına bağlıdır. $\mathrm{Bu}$ sebeple, kentsel yaban hayatıyla ilgili planlama büyük ölçüde kentin ve kentle bağlantılı yerlerde mevcut doğal alanların ve yeşil alanların planlanmasına ve bütüncül yaklaşıma (Aksu, 2021) dayanacaktır. Belirtilen tanımlama, bölge planları stratejik kararları ya da çevre düzeni planı kademesine karşılık gelmektedir.

$\mathrm{Bu}$ noktada kent peyzajını planlamada doğal stilin yeri ve önemine değinmek faydalı olacaktır. Zira, kentlerde yaban hayatının teşvik edilmesi ve ekolojik prensipler çerçevesinde doğal alanların artırılmasını öngören doğal stil peyzaj tasarımı ve uygulamaları özellikle Avrupa ve Amerika'da popüler hale gelmiştir (Kendle ve Forbes 1997; Özgüner, 2003)

Varsa kent içindeki doğal bitki örtüsünün korunması ile hem estetik değeri olan hem de yaban hayatını destekleyen yapılar kazanılmış olur (Dunnet 1995, Tregay 1986). Keza, peyzaj planlama araçlarını kullanmak suretiyle vejetasyona yönelik tasarım ve uygulamalar yapmak mümkündür. $\mathrm{Bu}$ yolla kent faunasını destekleyen dinamik bir sistem oluşturulabilir. Özellikle doğal stil peyzaj tasarım ve uygulamaları, klasik stile göre kentlerde daha çok çeşitlilik ve yaban hayatı için daha elverişli imkanlar sunmakta olup şehir yaban hayatı ve buna bağlı olarak çevre-doğa koruma hedefleri açısından daha uygun olduğu bildirilmektedir(Yates ve Ruff 1991, Özgüner, 2003). Peyzaj planında uygulama hedefleri: Bitki çeşitlilğini yüksek tutmak ve kabaca 1000 m2'den daha büyük monokültür (aynı türden oluşan bitki örtüsü) oluşturmaktan kaçınmak; doğal çalılıklar, taş yığınları, su kaynaklarının çevresi gibi farklı canlı türleri için habitat değeri taşıyan alanları korumak ve teşvik etmektir..

\subsubsection{Planlamada Beşeri Faktörler ve Katılımcılık}

Kent ortamında yaban hayatının canlanması, tanıtılması ve korumaya yönelik eylem planlarının geliştirilmesi için insan kaynakların harekete geçirilmesine yönelik bir planlama da yapılmalıdır. $\mathrm{Bu}$ konuda mevcut ve harekete geçirilebilecek potansiyel ile yeni potansiyelin oluşturulması için gereken aksiyon ve aktivitelere yönelik stratejilerin belirlenmesi lazımdır.

\subsection{Kent Hayatında Yaban Hayatı Uygulama ve Aktiviteleri}

Kentsel alanlarda yaban hayatına dikkat çekmek ve farkındalık oluşturmanın en kestirme ve etkili yolu başta kuş gözlemciliği olmak üzere bitki ve kelebek gözlemleri gibi yaban hayatı gözlem aktiviteleridir . Bu aktivitelere katılarak kent yaban hayatı ile tanışan kimseler bir süre sonra, kent flora ve faunasının korunmasına yönelik eylem planlarında görev alarak etkin roller oynayacaklardır. Gözlem ve koruma çalışmaları aynı zamanda kentiçi flora ve fauna hakkında planlama çalışmaları için işe yarar veriler sağlayacaklardır. Yaban hayatı farkındalığının artmasına paralel olarak kentsel mekanlarda koruma ihtiyacı olan alanlar ve öncelikleri ortaya çıkacak bu da yine kentsel planlama çalışmalarına 1 şı tutacaktır. Kent içi mekanlarda olduğu gibi hemen kent çevresindeki doğal alanlarda ise doğa yürüyüşleri düzenlenebilir. Yapılacak doğa yürüyüşleri ve bu yürüyüşler sırasında yapılan doğa gözlemleri kentiçi aktiviteleri besleyecek ve kent faunasını koruma çalışmalarına yeni yeni elemanlar kazandıracaktır. Belirtilen aktivite alanları, en alt kademedeki komşuluk gruplarının parklarından alt kademede başlayarak, üst kademeye- kent dişındaki alanlara kadar planlanabilir. En alt kademedeki parklarda yaban hayatına yaşam alanı sunabilecek, birkaç ağaç, çalı topluluğu vb. mekanlar sunulabilir. Bu mekanlar, uzman görüşüne göre, bitki türlerinin ve alansal büyüklüklerinin tanımlanması imar uygulama planı plan notlarında yer alabilir. Uygulama imar planı onaylanmasından sonraki uygulama ilgili idare denetiminde yapılacak, peyzaj plan çalışmalarını da kapsayan kentsel tasarım, ya da peyzaj düzenleme projesi ile yapılabilecektir.

Özetlemek gerekirse; kentin çevresiyle kurduğu ilişki, kent bütününden gelen yeşil sistemin, kent dışındaki kırsal alanlara bağlantısı ÇDP konusudur. Çevre düzeni planında kurulan yeşil strüktür, bir alt kademesindeki nazım planlara yol gösterecektir.

913 
Nazım planın, ÇDP'ndan aldı̆̆ı plan kararları, semt ya da mahalle ölçeğinde ifadelendirilecektir. Uygulama planı ise nazım plandaki yeşil sistem plan kararlarının, uygulanabilir nitelikte ayrıntılarını içeren en alt kademedir. Uygulama planı kararları, gereğinde kentsel tasarım ve peyzaj projeleri ile desteklenerek alanda hayata geçirilebilir.

Mekansal planların kademesi ve yaban hayatı niteliğine göre, planlarda detaylandırma yapılır. Gözden kaçmaması gereken konu, yaban hayatının kent ekosisteminde sürdürülebilirliğinin, plan kademeleri arasındaki bilgi akışının da hiyerarşik sistem bağlamında olması gerekliliğidir. Yaban hayatına ilişkin mekanda yapılan gözlemler, kademedeki en temel bilgi olarak planlama sistemine aktarılacak ve üst kademe planlara da kademesi bağlamında yansıyacaktır.

\subsubsection{Park ve Yeşil Alanlarda Gözlemler}

Çevre düzeni ve nazım imar planında genel sınırlar belirlenir, uygulama imar planında park ve yeşil alanlardaki alt işlevler kesin sinırları ile tanımlanarak planlanır, kentsel tasarım ve peyzaj projesinde gözlem alanları detaylandırılır.

\subsubsection{Yakın Çevre ve Doğa Gözlemleri}

Kırsal niteliği çağrıştıran doğa gözlemlerine ilişkin alanlar, daha çok çevre düzeni planı kapsamında planlanarak sınırları belirli bölgelerin farklı ölçeklerde peyzaj planları ile detaylandırılacağı, plan notlarına bağlanabilir.

\subsubsection{Kuş Gözlemciliği}

Yukarıdaki açıklamalar, kuş gözlemciliği için de geçerlidir. Kuş gözlemine konu olan geniş tabiat parçaları çevre düzeni planı kapsamına girmektedir. Kent içi kuş gözlem alanları ise ayrıca nazım plan ve peyzaj planında gösterilebilir. Mekânsal planlamada bitki ve kelebek gözlem alanları için de kuş gözlem alanları gibi düşünülebilir.

\subsubsection{Yaban Hayatının Tanttımı ve Aktivite Planlama}

Yukarıda bahsedildiği gibi gözlem, yürüyüş gibi planlanacak her türlü aktivite kent için yaban hayatı unsurlarının tanıtımına hizmet edecektir. Bu aktivitelerin mekanı ise kentsel planlamada birden fazla yerleşmeyi kapsayan alanlarda ÇDP, yerleşme bütününde nazım imar planı ile işaret edilen alanlar olacaktır.

\subsubsection{Yaban Hayatına Uygun Alan ve Mekânların Oluşturulmast}

Kent içinde yaban hayatına uygun alanların veya mekânların oluşturulması tüm kademe fiziki planlardan itibaren ele alınacak bir konudur. Yeşil alanların yaban hayatını destekleyen alanlar olduğu kabulüyle hareket edersek, yaban hayatına elverecek alanların sınırları ÇDP ve nazım planda, detaylar da uygulama planı ve peyzaj projelerinde belirtilmiş olacaktır.

\section{Sonuç}

Kentsel alanların sürekli büyümesi ve yapılaşma eğilimi göstermesi kent içi ve dışı yeşil alanların azalmasına veya daralmasına yol açmaktadır. Yaban hayatı için yaşam mekanı (Barınma, beslenme vb )olarak kullandıkları doğal alanlar veya yeşil alanların korunması ve yaşatılması büyük önem taşımaktadır. $\mathrm{Bu}$ nedenle Kent planlarının da kent içi ve çevresindeki mevcut doğal alanlar ve yeşil alanların korunması, yeni alanların oluşturulması ve bu alanların kendi arasında mutlaka yeşil koridorlarla birbirlerine bağlanması, yaban hayatının korunması ve devamlılığın sağlanmasını mümkün hale getirebilecektir. Büyük şehirlerde dönüşüm, toprak yüzeyinin ve yeşil dokunun azalması yönünde oluşmaktadır. Bu nedenle yeşil dokuyu oluşturan ağaç-çalı ve her türlü bitki örtüsü ve bunu besleyen toprak zeminin korunması, planlamanın esas hedefidir.. $\mathrm{Bu}$ hedef doğrultusunda farklı ölçekte planlar için ara hedefler belirlemek ve buna yönelik uygulamalar gerçekleştirmek mümkündür. Planlar doğal yaşam alanlarının sürdürülebilirliğini sağlama amacına yönelik olarak hazırlanan araçlardır. Planların amaçlarına ulaşabilmesi ise, hiyerarşik düzende kurgulanması ve uygulanmasını gerektirir. Bu nedenle yasal ve yönetsel sistemin sürdürülebilirlik çerçevesindeki uygulamaları desteklemesi gerekmektedir. İnsan eliyle oluşan yapay sistemin doğal sistem üzerindeki baskısının boyutları ancak üst kademe planlarda anlaşılabilir. Bu nedenle ÇDP'nın yasal sistemde zorunlu planlar kapsamına alınması ve tüm kademe planlarda ekolojik temele dayalı ilkelerin belirlenmesinde yarar vardır. Planların uygulanabilir nitelikte yapılması, uygulama akışının farklı yasal düzenlemelerle kesintiye uğramaması, uygulama denetiminin aksatılmadan yürütülmesi yaban hayatının planlarda yer verildiği şekliyle sürdürülmesinde etkili olacaktır. Yaban hayatının devamlılığını sağlayan yeşil sistemin korunması, takip edilmesi, mevcut sistemin zarar görmemesi adına farkındalık oluşturan sosyal faaliyetler ve bilinçlendirme, kent hayatı içinde yaban hayatının korunmasında etkili bir yaklaşım olacaktır.

\section{Kaynakça}

Aksu, G. A., (2021). Kentsel Peyzajlarda Yol Kenarı Yeşil Alanların Kent Ekosistemi Çerçevesinde Değerlendirilmesi. Avrupa Bilim ve Teknoloji Dergisi, (25), 736-748

Aydın, B., (2010), Gelişme Alanlarında Ekolojik Kentsel Yerleşim Kriterlerinin Belirlenmesi Ve İmar Planı Kapsamında Yorumlanmas1: Ömerli Havzası Sancaktepe Örneği, Yüksek Lisans Tezi, İstanbul Teknik Üniversitesi, Fen Bilimleri Enstitüsü

Deniz, vd., (2006), Peyzaj Ekolojisine Genel Bakış, ADÜ Ziraat Fakültesi Dergisi, 3(2), 5-18

Dunnet, N., (1995), Patterns in nature: inspiration for ecological landscape design. In G. H. Griffiths (Ed), Landscape Ecology: Theory and Application, Proceedings of the 4th Annual Conference of IALE held at The University of Reading, pp. 78-85

Emery, M., (1986), Promoting Nature in Cities and Towns: A Practical Guide. Croom Helm, London

Flint, R., (1985), Encouraging Wildlife in Urban Parks: Guidelines to Management. The London Wildlife Trust, Gordon Press, London

Forman, R. T. T., (1995), Land Mosaics, The Ecology of Landscapes and Regions, Cambridge University Pres.

Güngöroğlu, C., (2008), Almanya Örneğinde Peyzaj Yaklaşımı. Batı Akdeniz Ormancılık Araştırma Müdürlüğü Dergisi, Cilt 1, Say1 9, S. 43-56.

Kendle, A. D., Forbes, S. J., (1997), Urban Nature Conservation: Landscape Management in the Urban Countryside. E \& FN Spon, London

Kennedy, C. E. J., Southwood, T. R. E. (1984), The number of insects associated with British trees: a re-analysis. Journal of Animal Ecology, 53: 455-478

Marzluff ., M. J., Shulenberger E., Endlicher W., Alberti M, Bradley G.,Ryan., C. ZumBrunnen C., Simon U., (2008). Urban Ecology An International Perspective on the 914 
Interaction Between Humans and Nature. Springer Science+Business Media, New York

Mol..T., (2006), Yaban Hayat1, İstanbul Üniversitesi Orman Fakültesi Yayınları İ.Ü. Yayın No: 4643, O.F Yayın no 489, ISBN No: 975-404-766-9. İstanbul

Oğurlu, İ.. (2003), Yaban Hayatında Envanter, T.C Çevre ve Orman Bakanlığı Doğa Koruma ve Milli Parklar Genel Müdürlüğü Av ve Yaban Hayatı Dairesi Başkanlığı Matbaası, Ankara, , 208s.

Ogurlu, İ., Gündoğdu, E., Ünal, Y., Kilimci, Ü., ( 2004), Bird Observations in Isparta (1999-2003), 1st International Eurasian Ornithology Congress, 8-11 April, Antalya-Turkey

Oğurlu, İ., Ünal, Y., Aksan, Ş., (2010), Yaban Hayatında Biyorestorasyon, III. Ulusal Karadeniz Ormancılık Kongresi Cilt:I Sayfa 1225-1231, 20-22, Mayıs, 2010, Artvin Çoruh Üniversitesi, ARTVIN

Oğurlu, İ., (2014), Çevre- Kent İmaj1 - Kent Kimliği- Kent Kültürü Etkileşimlerine Bir Bakış, İstanbul Ticaret Üniversitesi Fen Bilimleri Dergisi, 1(26), 275-294,

Oğurlu, İ., 2016. Yaban Hayatı Ekolojisi, Süleyman Demirel Üniversitesi Orman Fakültesi Yayın No: 19. Isparta, s.297

Öymen T., (2008), Yaban Hayatı Bilgisi Temel Kavramlar ve Yaban Hayatı Yönetimi, İstanbul Üniversitesi Orman Fakültesi Yayınları İ.Ü. Yayın No: 4643, O.F Yayın no 489, ISBN No: 975-404-766-9. İstanbul

Özgüner, H., (2003). Kentsel Peyzajda Doğal Stilin Fonksiyonel Değerleri ve Bunların Klasik Stille Karşılaştırılması, Süleyman Demirel Üniversitesi Orman Fakültesi Dergisi, Seri: A, Say1: 2, ISSN: 1302-7085, Sayfa: 19-36

Resmi Gazete, (2014), Mekânsal Planlar Yapım Yönetmeliği $29030 / 2014$

Suri, L., (2020). Criterıa For Determınıng Water Basın Boundary And The Importance Plannıng Decisions In Sustainıng Water Resources. Fresenıus Environmental Bulletın, 29(5), 37643777

Suri, L., (2017), Kent Merkezlerini Planlama İlkeleri, Basılmamış Ders Notları, İstanbul Ticaret Üniversitesi

Xiurui, G., Xianqiang M., Jurong, Y., Zhifeng, Y., (2005), China population resources and environment. Vol. 15 no. 5 pp. 126130. China

Tuna, A (2021), İngiltere'de Yeşil Altyapı Kavramının Uygulama Örnekleri Üzerinden İrdelenmesi, Avrupa Bilim ve Teknoloji Dergisi,(21), 416-423.

Tregay, R. (1986), Design and ecology in the management of nature like plantations. In A. D. Bradshaw, D. A. Goode, and E. H. P. Thorp (Eds), Ecology and Design in the Landscape, Blackwell Scientific Publications, pp. 275-284

Yates, D. and Ruff, A. R. (1991), Encouraging nature in urban parks. Occasional Paper No: 30, Department of Planning and Landscape, University of Manchester 